\title{
Effect of ractopamine on the chemical and physical characteristics of pacu (Piaractus mesopotamicus) steaks
}

\author{
[Efeito da ractopamina sobre as características físicas e químicas de filés \\ de pacu (Piaractus mesopotamicus)] \\ L.M.F.S. Oliveira, R.S. Leal, T.C. Mesquita, M.E.S.G. Pimenta*, M.G. Zangeronimo, \\ R.V. Sousa, R.R. Alvarenga \\ Universidade Federal de Lavras - UFLA - Lavras, MG
}

\begin{abstract}
The objective was to evaluate the use of ractopamine (RAC) in the diet for pacu (Piaractus mesopotaminus) in the finishing phase on some quality parameters of the fillets. Thirty-five animals weighing $0.868 \pm 0.168 \mathrm{~kg}$ were distributed in a completely randomised design with five treatments $(0.0$ control; 11.25, 22.50, 33.75 and $45 \mathrm{ppm}$ of RAC) and seven replicates with two fillets obtained from the same animal. The diets were isocaloric and isoprotein and experimental time was 90 days. RAC did not affect $(\mathrm{P}>0.05)$ the initial $\mathrm{pH}$ or $\mathrm{ph}$ after 24 hours of the fillets. Compared to the control, RAC increased $(\mathrm{P}<0.05)$ the moisture content of the fillets in natura and lipid oxidation of samples stored for 12 days in the refrigerator or freezer for 60 days. The RAC in $11.25 \mathrm{ppm}$ reduced $(\mathrm{P}<0.05)$ the lipid content, while $45 \mathrm{ppm}$ reduced $(\mathrm{P}<0.05)$ the crude protein in the fillets. Considering only $\mathrm{RAC}$, there was a linear increase $(\mathrm{P}<0.05)$ in the lipid content $(\mathrm{P}<0.05)$ and a linear reduction in crude protein and weight loss after cooking the fillets. There was a quadratic effect $(\mathrm{P}<0.05)$ on the ash content, weight loss and lipid oxidation in fillets stored in the refrigerator or freezer. A RAC dose of $33.75 \mathrm{ppm}$ resulted in a lower lipid oxidation index. In conclusion, ractopamine at $11.25 \mathrm{ppm}$ is effective for reducing the fat content in fillets of pacu, although it increases the formation of peroxides in samples kept in the freezer for longer than 60 days. At $33.75 \mathrm{ppm}$, ractopamine is effective in reducing the effect of oxidation during storage in the refrigerator or freezer.
\end{abstract}

Keywords: fish, lipid oxidation, animal production, fillet quality

\section{RESUMO}

O objetivo foi avaliar a influência do uso de ractopamina na alimentação de pacus (Piaractus mesopotaminus) na fase de terminação sobre alguns parâmetros de qualidade dos filés. Trinta e cinco animais com peso de 0,868 $\pm 0,168 \mathrm{~kg}$ foram distribuídos em delineamento inteiramente ao acaso com cinco tratamentos $(0,0$ - controle; 11,25; 22,50; 33,75 e 45ppm de ractopamina) e sete repetições, sendo a parcela representada por dois filés provenientes de um animal. As rações foram isoenergéticas $e$ isoproteicas, e o tempo experimental foi de 90 dias. A ractopamina não influenciou $(P>0,05)$ o pH inicial dos filés e nem após 24 horas. Comparado ao controle, a RAC aumentou $(P<0,05)$ a umidade dos filés in natura $e$ a oxidação lipídica dos mesmos quando armazenados por 12 dias em geladeira ou 60 dias em freezer. Na dose de 11,25 reduziu $(P<0,05)$ o teor de extrato etéreo e, na dose de 45 ppm, reduziu $(P<0,05)$ o de proteína bruta dos filés. Considerando somente a RAC, houve aumento linear $(P<0,05)$ do teor de gordura e redução linear $(P<0,05)$ da proteína bruta e perda de peso por cocção. Houve efeito quadrático $(P<0,05)$ sobre o teor de cinzas, perda de peso por descongelamento e oxidação lipídica para os filés armazenados em geladeira ou em freezer, sendo 33,75 ppm o nível de RAC que resultou em menor índice de oxidação lipídica. Conclui-se que a ractopamina a 11,5 ppm é efetiva em reduzir o teor de lipídeos em filés de pacu, embora aumente a formação de peróxidos em amostras mantidas em freezer

Recebido em 25 de outubro de 2012

Aceito em 17 de julho de 2013

*Autor para correspondência (corresponding author)

E-mail: maria.emilia@dca.ufla.br 
após 60 dias. A 33,75 ppm a ractopamina é efetiva em reduzir os efeitos da oxidação durante o armazenamento em geladeira ou freezer.

Palavras-chave: peixe, oxidação lipídica, piscicultura, qualidade de filé

\section{INTRODUCTION}

Aquaculture represents an important activity in food production in Brazil. The necessity of increasing productivity in terms of quantity and quality (foods with lower fat levels, for example) has fostered intense growth in aquaculture. In this context, farmers seek to invest in species with high productivity and low fat deposition in the carcass.

The pacu (Piaractus mesopotamicus) is an omnivorous and migratory fish originating in the Paraguay and Parana rivers. This native species has been adopted by fish farmers due to its acceptance, reproducibility and adaptation to the conditions of captivity. However, the meat has a high fat content. Studies show that the highest deposition occurs in the finishing phase (Povh et al., 2009; Bicudo et al., 2010).

In the search for improved meat quality and production performance, additives have been used to modify metabolism in several species. Ractopamine is a $\beta$-adrenergic agonist that alters nutrient metabolism, redirecting nutrients to protein rather than lipid anabolism, which helps to improve production indices and meat quality (Mersmann, 1998; Van den Berg and Moccia, 1998; Haji-Abadi et al., 2010).

In fish, administration of ractopamine was previously reported with some positive results in terms of increasing the protein content and reducing lipid levels in the meat (Van den Berg and Moccia, 1998; Van den Berg et al. 1998). The results were less obvious than those observed in mammals; however, this additive can alter other characteristics of meat due to alterations in post mortem metabolism.

Studies conducted with different species of fish used variable doses ranging from $10 \mathrm{mg} / \mathrm{kg}$ (Haji-Abadi et al., 2010) to $100 \mathrm{mg} / \mathrm{kg}$ (Mustin and Lovell, 1993). Thus, further studies are needed to determine the most appropriate dose to use in pacus under Brazilian conditions.
This study aimed to evaluate aspects related to meat quality in pacus fed diets with different levels of ractopamine in the finishing phase.

\section{MATERIAL AND METHODS}

The experiment was conducted from September 2010 to March 2011 at the Laboratory of Fish Metabolism of Fish Culture Station of the Federal University of Lavras, Minas Gerais, Brazil. The geographical coordinates are $21^{\circ} 14 ' 43^{\prime \prime}$ latitude and $-44^{\circ} 59^{\prime} 59^{\prime \prime}$ longitude. The altitude is $919 \mathrm{~m}$.

Thirty-five animals weighing $0.868 \pm 0.168 \mathrm{~kg}$ were randomly divided into individual experimental aquaria with a capacity of $100 \mathrm{~L}$ and equipped with an automated circulation system, biological and physical filters. The water temperature was maintained between 25 and $28^{\circ} \mathrm{C}$.

A completely randomised design was used with four treatments (ractopamine levels) plus a control with seven replicates of two steaks per plot. For the assessment of malonic dialdehyde concentrations, samples were kept in the refrigerator or freezer and the same design was used, but subdivided in time (four time points).

The experimental diets (Table 1) were isocaloric and isonutrient, and were comprised of corn, soybean meal, fish meal and wheat bran and supplemented with vitamins, minerals and amino acids to meet the requirements of the species in accordance with Boscolo et al. (2011), with the exception of protein, which was increased to $32 \%$ due to increased protein synthesis in animals fed with diets containing ractopamine (Mitchell et al., 1990).

The experimental period was 90 days. Initially, two weeks were used for the adjustment of the animals to the experimental conditions. During this time, animals were fed a basal diet without the addition of ractopamine. The fish were fed $a d$ libitum twice a day (8:00 and 16:00) throughout the experimental period. 
At the end of the experiment, after fasting for 12 hours, the animals were slaughtered for carcass evaluations. After stunning the fish with a benzocaine solution $(50 \mathrm{mg} / \mathrm{L})$, the animals were submitted to spinal section. After this, they were gutted and filleted. The fillets were taken to the Central Analytical Laboratory of the Department of Food Science of the Federal University of
Lavras, where the $\mathrm{pH}$ was measured using an electrode (Bernauer portable digital $\mathrm{pH}$ meter model F-1002, Blumenau, Brazil) placed in three different points of each sample fillet. The average value was considered as the result. This procedure was repeated 24 hours later in samples stored under refrigeration at $4^{\circ} \mathrm{C}$.

Table 1. Experimental diets composition

\begin{tabular}{|c|c|c|c|c|c|}
\hline \multirow{2}{*}{ Ingredients $(\%)$} & \multicolumn{5}{|c|}{ Ractopamine (ppm) } \\
\hline & 0.00 & 11.25 & 22.50 & 33.75 & 45.00 \\
\hline Soybean meal $45 \%$ & 50.00 & 50.00 & 50.00 & 50.00 & 50.00 \\
\hline Fish flour $74 \%$ & 8.00 & 8.00 & 8.00 & 8.00 & 8.00 \\
\hline Corn & 24.90 & 24.90 & 24.90 & 24.90 & 24.90 \\
\hline Wheat flour & 8.00 & 8.00 & 8.00 & 8.00 & 8.00 \\
\hline L-lysine $\mathrm{HCl} 78 \%$ & 0.19 & 0.19 & 0.19 & 0.19 & 0.19 \\
\hline DL-methionine $98 \%$ & 0.28 & 0.28 & 0.28 & 0.28 & 0.28 \\
\hline L-threonine $99 \%$ & 0.05 & 0.05 & 0.05 & 0.05 & 0.05 \\
\hline Soybean oil & 4.00 & 4.00 & 4.00 & 4.00 & 4.00 \\
\hline Bicalcium phosphate & 3.80 & 3.80 & 3.80 & 3.80 & 3.80 \\
\hline Acorbic acid & 0.06 & 0.06 & 0.06 & 0.06 & 0.06 \\
\hline Salt & 0.20 & 0.20 & 0.20 & 0.20 & 0.20 \\
\hline Premix $^{1}$ & 0.50 & 0.50 & 0.50 & 0.50 & 0.50 \\
\hline Butil hydroxy toluene & 0.02 & 0.02 & 0.02 & 0.02 & 0.02 \\
\hline Ractopamine hydrochloride $2.05 \%$ & 0.00 & 0.1125 & 0.2250 & 0.3375 & 0.4500 \\
\hline \multicolumn{6}{|l|}{ Calculated composition ${ }^{3}$} \\
\hline Digestible energy (Kcal) & 3203 & 3203 & 3203 & 3203 & 3203 \\
\hline Crude protein $(\%)$ & 32.26 & 32.26 & 32.26 & 32.26 & 32.26 \\
\hline Digestible protein $(\%)$ & 27.56 & 27.56 & 27.56 & 27.56 & 27.56 \\
\hline Crude fiber $(\%)$ & 4.19 & 4.19 & 4.19 & 4.19 & 4.19 \\
\hline Ether extract $(\%)$ & 7.06 & 7.06 & 7.06 & 7.06 & 7.06 \\
\hline Calcium (\%) & 1.48 & 1.48 & 1.48 & 1.48 & 1.48 \\
\hline Available phosphorus (\%) & 0.81 & 0.81 & 0.81 & 0.81 & 0.81 \\
\hline Methionine (\%) & 0.62 & 0.62 & 0.62 & 0.62 & 0.62 \\
\hline Lysine (\%) & 1.95 & 1.95 & 1.95 & 1.95 & 1.95 \\
\hline Triptophan (\%) & 0.38 & 0.38 & 0.38 & 0.38 & 0.38 \\
\hline Threonine (\%) & 1.13 & 1.13 & 1.13 & 1.13 & 1.13 \\
\hline
\end{tabular}

${ }^{\mathrm{I}}$ Composition per kg of product: $1500 \mathrm{UI}$ of vitamin A, 20mg of vitamin B1, 15mg of vitamin B2, 1000 UI of vitamin B3, $10 \mathrm{mcg}$ of vitamin B12, 25mg of vitamin E, 120mg of vitamin PP, 2,000mg of choline, $80 \mathrm{mg}$ of calcium pantothenate, $2.0 \mathrm{mg}$ of folic acid, $80 \mathrm{mg}$ of manganese, $24 \mathrm{mg}$ of iron, $50 \mathrm{mg}$ of zinc, $8.0 \mathrm{mg}$ of cupper, $3.0 \mathrm{mg}$ of iodine, $0.10 \mathrm{mg}$ of selenium and $170 \mathrm{mg}$ of butil hydroxy toluene.

${ }^{2}$ According Furuya et al. (2004).

Weight loss by thawing and cooking was determined by subtracting the weight of the fresh samples taken from the fillets before and after cooling and heat treatment, using the same methodology proposed by Moreira (2005) for broilers.

Proximate analysis of the steak samples was done using the methodology proposed by AOAC (Association..., 1995). All analyses were performed in triplicate. The analysis of moisture and ash were performed on cooled fresh fillets and the analysis of lipids and protein were conducted on lyophilised samples of fillets (Freeze-Liobras Model L202, San Carlos, Brazil). The moisture content was determined by a gravimetric method after oven drying to a constant weight. The lipid content was assessed by the Soxhlet method and crude protein by the Microkjeldhal method in free fat samples. The 
ash content was determined by a gravimetric method using a muffle furnace at $550^{\circ} \mathrm{C}$.

For the assessment of lipid oxidation, the TBARS (thiobarbituric acid reactive substances) test was used, according Tarladgis et al. (1960). The initial analysis was performed immediately after the slaughter of the animals (time zero) and on the $4^{\text {th }}, 8^{\text {th }}$ and $12^{\text {th }}$ days of storage in the refrigerator $\left(\sim 4^{\circ} \mathrm{C}\right)$ and on the $15^{\text {th }}, 30^{\text {th }}$ and $60^{\text {th }}$ days of storage in the freezer $\left(\sim-10^{\circ} \mathrm{C}\right)$. All analyses were performed in triplicate using a spectrophotometer (Varian, Inc.; Cary Model 50 UV-Vis Spectrophotometer, Porto Alegre, Brazil), adjusted to $531 \mathrm{~nm}$. The absorbance values were multiplied by a constant (7.38) to estimate the amount of malonic dialdehyde per $\mathrm{kg}$ of sample (Tarladgis et al. 1960).

Data was subjected to analysis of variance after a normality test (Shapiro-Wilk). The values obtained with ractopamine treatment were submitted to regression analysis. The Dunnett test was used to compare the control with each level of ractopamine. For the ash, ether extract, crude protein, weight loss by thawing or cooking and malonic dialdehyde concentration in fillet samples, the square root transformation of data was used. To compare lipid oxidation over time, the SNK test at 5\% was used. All statistical analyses were performed using the statistical Sisvar package version 5.3.

\section{RESULTS AND DISCUSSION}

Among the analysed variables, ractopamine had no effect $(\mathrm{P}>0.05)$ on the initial $\mathrm{pH}$ or on the $\mathrm{pH}$ 24 hours after slaughter (Table 2). The analysis of these indices aims to determine the reduction in $\mathrm{pH}$ in meat during and after the rigor mortis process. This $\mathrm{pH}$ reduction is important to the quality of the meat. In fish, these values should remain below 6.45 (Batista et al., 2004). In the present work, all the $\mathrm{pH}$ values after slaughter were close to 7.0, as expected, and showed a significant decrease after $24 \mathrm{~h}$. This acidification prevents bacterial deterioration of the meat. No studies in the literature were found relating the use of ractopamine in fish and its effect on $\mathrm{pH}$ values. In the present work, no correlation between this variable and ractopamine dose was observed.

Table 2. Chemical composition, $\mathrm{pH}$ and weight lost by thawing and by cooking of fillets of pacus (Piaractus mesopotamicus) fed diets containing different levels of ractopamine during finishing phase

\begin{tabular}{|c|c|c|c|c|c|c|c|}
\hline \multirow{2}{*}{ Variable } & \multicolumn{4}{|c|}{ Ractopamine (ppm) } & \multirow{2}{*}{ Control } & \multirow{2}{*}{$\begin{array}{l}\text { Coefficient of } \\
\text { variation }(\%)\end{array}$} & \multirow{2}{*}{$\begin{array}{c}\mathrm{P} \\
\text { value }\end{array}$} \\
\hline & 11.25 & 22.5 & 33.75 & 45.0 & & & \\
\hline Initial $\mathrm{pH}$ & 7.45 & 7.34 & 7.44 & 7.40 & 7.48 & 2.43 & 0.64 \\
\hline Final $\mathrm{pH}$ & 6.14 & 6.26 & 6.35 & 6.25 & 6.13 & 3.75 & 0.40 \\
\hline Humidity (\%) & $72.3 *$ & $70.9 *$ & $72.4^{*}$ & $71.8^{*}$ & 65.94 & 3.24 & 0.62 \\
\hline $\operatorname{Ash}(\%)^{1}$ & 1.27 & 1.33 & 1.46 & 1.20 & 1.29 & 7.69 & 0.04 \\
\hline Ether extract $(\%)^{2}$ & $8.98 *$ & 18.21 & 17.87 & 21.26 & 21.49 & 8.42 & $<0.01$ \\
\hline Crude protein $(\%)^{2}$ & 17.72 & 18.71 & 16.94 & $13.08 *$ & 19.55 & 9.57 & 0.08 \\
\hline \multicolumn{8}{|l|}{ Weight lost } \\
\hline By thawing $(\%)^{1}$ & 14.32 & 10.75 & 13.84 & 15.48 & 14.90 & 12.44 & 0.031 \\
\hline By cooking $(\%)^{2}$ & $2.07 *$ & $2.35^{*}$ & 1.18 & 0.86 & 1.03 & 23.29 & $<0.01$ \\
\hline
\end{tabular}

* Differ of control by Dunnett test $(\mathrm{P}<0.05)$

${ }^{1}$ Quadratic regression $(\mathrm{P}<0.05)$

${ }^{2}$ Linear regression $(\mathrm{P}<0.05)$

Regarding the moisture content in fillets, ractopamine increased $(\mathrm{P}<0.05)$ the values compared to control; however, no differences $(\mathrm{P}>0.05)$ were observed between doses. Ractopamine has the effect of increasing the water holding capacity (WHC), which would cause an increase in the moisture content in fillets (Rosenvold and Andersen, 2003). The WHC and moisture are important for several reasons, such as the fact that meat exudation occurs as a result of a lower capacity for water retention. This compromises the appearance of the meat and leads to yield losses of products. Thus, moisture and the WHC influence the perception of the texture of fresh meat after cooking (Rosenvold and Andersen, 2003). In a study conducted by Moccia et al. (1998) with rainbow trout, the authors did not observe an effect on the moisture content in fish meat using the same levels of ractopamine. 
The levels of ractopamine had a quadratic effect $(\mathrm{P}<0.05)$ on the ash content, with a gradual increase until $29 \mathrm{ppm}$ (Figure 1). In assessing the proximate composition of pacus fillets, ash values were within expectations for this species (Bicudo et al., 2010; Tanamati et al., 2009), which is an important nutritional component in food.

The fat content of the fillets increased linearly $(\mathrm{P}<0.05)$ with the dose of ractopamine. Compared to the control, only the dose of 11.25 ppm resulted $(\mathrm{P}<0.05)$ in a lower fat content. With respect to the protein content, a linear decrease $(\mathrm{P}<0.05)$ was observed in relation to ractopamine dose. Compared to the control, the dose of $45 \mathrm{ppm}$ resulted $(\mathrm{P}<0.05)$ in a lower protein content in the fillets. It is known that ractopamine is capable of altering lipid and protein metabolism in several species of farm animals (Haji-Abadi et al., 2010). The effects of ractopamine on the composition of the fillets can be explained by the activation of $\beta$-adrenergic receptors, leading to the activation of hormonesensitive lipase by phosphorylation, thus initiating lipolysis in adipocytes (Mersmann, 2002; Ferreira et al., 2011). In response to this lipolysis, fatty acids are released for use as an energy source in other tissues (Mersmann, 2002; Salem et al., 2006; Haji-Abadi et al., 2010).

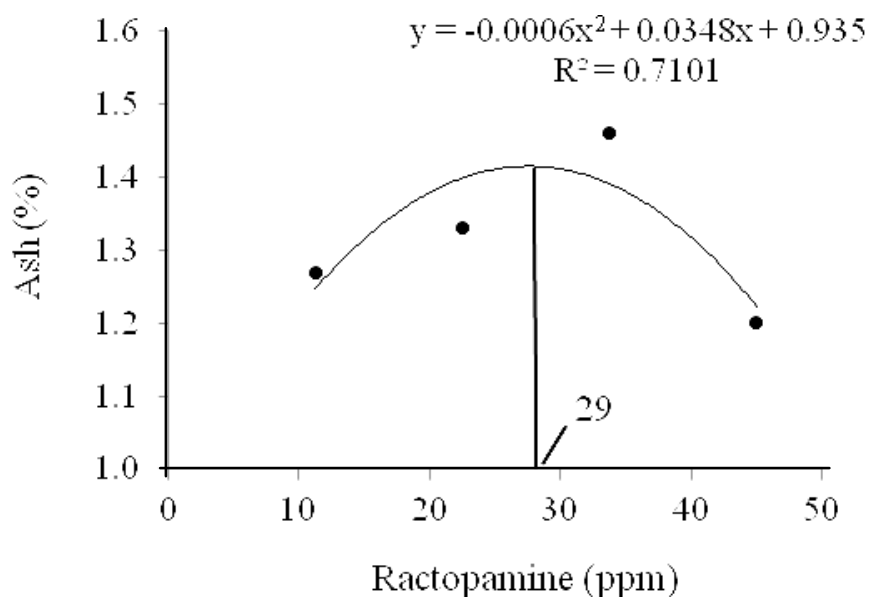

Figure 1. Ash concentration (\%) of fillets of pacus (Piaractus mesopotamicus) fed diets containing different levels of ractopamine during finishing phase.

The lipolytic action of $\beta$-adrenergic receptors in adipose tissue occurs in mammals; however, a study on rainbow trout (O. mykiss) (Van Heeswijk et al., 2006) showed that noradrenaline and adrenaline (natural $\beta$-agonists) reduce the lipolysis rate in adipocytes. In another study with rainbow trout, the release of free fatty acids in the liver was observed (Haji-Abadi et al., 2010). In catfish (Ictalurus punctatus and I. furcatus), Mustin and Lovell (1993) used $20 \mathrm{mg} / \mathrm{kg}$ of ractopamine in a high-protein diet and showed similar results to those found in mammals. But, in this case, they observed a greater effect with an increase in the protein content in the diet.

In another study, Van den Berg and Moccia (1998) evaluated the effect of ractopamine $(0,5$,
10, 20 and 40ppm) on trout carcass composition. The authors observed a reduction in the fat content with $10 \mathrm{ppm}$ of ractopamine, while 40 ppm increased the fat content compared to the control group, similar to what was observed in the present work. At high levels of ractopamine, it is believed that desensitisation of adrenergic receptors may occur (Ferreira et al., 2011).

The ractopamine dose influenced weight loss $(\mathrm{P}<0.05)$ in a quadratic fashion by thawing; however, no level of this additive differed from control (P>0.05). The optimal level of ractopamine, which resulted in lower thawing weight loss, was 25ppm (Figure 2). 


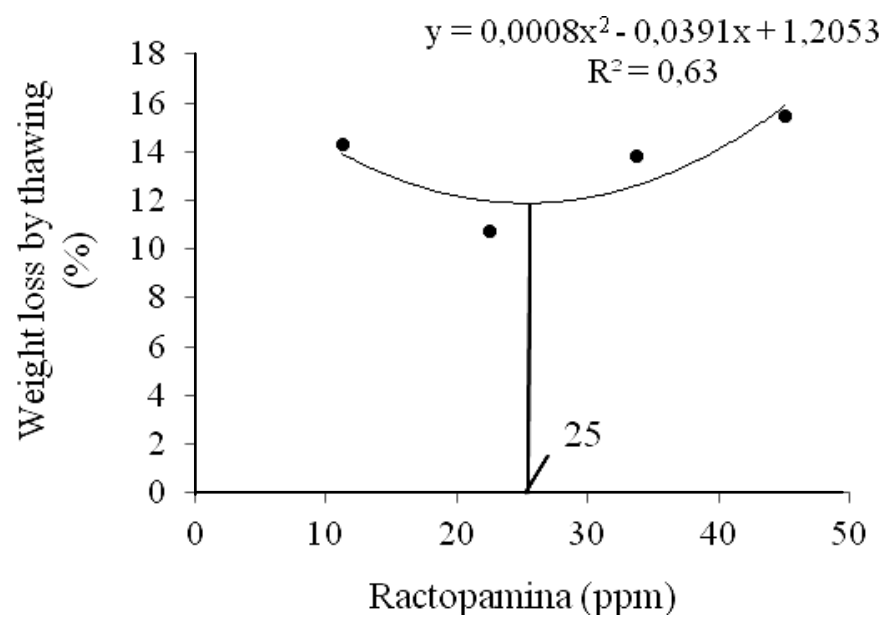

Figure 2. Weight loss by thawing (\%) of fillets of pacus (Piaractus mesopotamicus) fed diets containing different levels of ractopamine during finishing phase.

Ractopamine linearly reduced $(\mathrm{P}<0.05)$ the weight loss by cooking. Compared to the control, the doses of 22.5 and $11.25 \mathrm{ppm}$ of ractopamine resulted $(\mathrm{P}<0.05)$ in higher losses. The increase in water retention capacity promotes a reduction in weight loss by thawing and cooking; this capacity can be associated with moisture (Webster et al. 1995; Rosenvold and Andersen, 2003), but this effect was not apparent in the present work and no effect was observed on the moisture content.
Compared to the control, ractopamine at a dose of $45 \mathrm{ppm}$ increased $(\mathrm{P}<0.01)$ the malonic dialdehyde content in chilled fillets when stored for 12 days in the refrigerator (Table 3). This effect was not observed with lower doses of the additive. A level of $33.75 \mathrm{ppm}$ reduced $(\mathrm{P}<0.01)$ the malonic dialdehyde content. Between the ractopamine diets, there was a quadratic effect $(\mathrm{P}<0.01)$ in samples stored for 8 and 12 days in the refrigerator, at doses of 30 and 26ppm, respectively; these doses led to lower concentrations of malondialdehyde (Figure $3)$.

Table 3. Average concentration of malonic dialdehyde $(\mathrm{mg} / \mathrm{kg})$ in stored fillets of pacus (Piaractus mesopotamicus) fed diets containing different levels of ractopamine during finishing phase

\begin{tabular}{|c|c|c|c|c|c|c|c|}
\hline \multirow{2}{*}{ Storage way } & \multirow{2}{*}{$\begin{array}{c}\text { Day of } \\
\text { evaluation }\end{array}$} & \multicolumn{4}{|c|}{ Ractopamine (ppm) } & \multirow{2}{*}{ Control } & \multirow{2}{*}{$\begin{array}{l}\text { Coefficient of } \\
\text { variation }(\%)\end{array}$} \\
\hline & & 11.25 & 22.5 & 33.75 & 45 & & \\
\hline \multirow{4}{*}{$\begin{array}{l}\text { Refrigerator } \\
\qquad\left(4^{\circ} \mathrm{C}\right)\end{array}$} & 0 & $0.132 \mathrm{a}$ & $0.137 \mathrm{a}$ & $0.140 \mathrm{a}$ & $0.149 \mathrm{a}$ & $0.144 \mathrm{a}$ & \multirow[t]{4}{*}{14.36} \\
\hline & 4 & $0.235 \mathrm{a}$ & $0.184 \mathrm{a}$ & $0.174 \mathrm{a}$ & $0.220 \mathrm{a}$ & $0.190 \mathrm{a}$ & \\
\hline & $8^{1}$ & $0.532 \mathrm{~b}$ & $0.249 \mathrm{a}$ & $0.422 \mathrm{~b}$ & $0.417 \mathrm{~b}$ & $0.321 \mathrm{a}$ & \\
\hline & $12^{1}$ & $1.166 \mathrm{c}$ & $1.157 \mathrm{~b}$ & $0.783 c^{*}$ & $1.549 \mathrm{c}^{*}$ & $1.118 \mathrm{~b}$ & \\
\hline \multirow{7}{*}{$\begin{array}{l}\text { Freezer } \\
\left(-10^{\circ} \mathrm{C}\right)\end{array}$} & 0 & $0.132 \mathrm{a}$ & $0.137 \mathrm{a}$ & $0.153 \mathrm{a}$ & $0.149 \mathrm{a}$ & $0.144 \mathrm{a}$ & 13.91 \\
\hline & 15 & $0.145 \mathrm{a}$ & $0.107 \mathrm{a}$ & $0.168 \mathrm{a}$ & $0.129 \mathrm{a}$ & $0.131 \mathrm{a}$ & \\
\hline & 30 & $0.091 \mathrm{a}$ & $0.097 \mathrm{a}$ & $0.067 \mathrm{a}$ & $0.115 \mathrm{a}$ & $0.082 \mathrm{a}$ & \\
\hline & $60^{1}$ & $0.806 b^{*}$ & $0.882 b^{*}$ & $0.591 \mathrm{~b}$ & $1.056 b^{*}$ & $0.652 \mathrm{~b}$ & \\
\hline & & \multicolumn{3}{|c|}{$\mathrm{P}$ value } & & & \\
\hline & & RAC & Dia & $\mathrm{R} * \mathrm{D}$ & & & \\
\hline & & $<0.01$ & $<0.01$ & $<0.01$ & & & \\
\hline
\end{tabular}

*Differ of control by Dunnet test $(\mathrm{P}<0.05)$

Means followed by different letters in column differ by SNK test $(\mathrm{P}<0.05)$

${ }^{1}$ Quadratic regression $(\mathrm{P}<0.05)$ 
As for durability under refrigeration, a ractopamine dose of $33.75 \mathrm{ppm}$ was associated with the lowest concentration of malonic dialdehyde over time. The samples remained stable in relation to lipid oxidation during the entire period of evaluation.

Ractopamine did not affect $(\mathrm{P}>0.05)$ the malonic dialdehyde concentration in frozen steaks stored for 30 days. At 60 days, ractopamine increased $(\mathrm{P}<0.01)$ the concentration of this substance

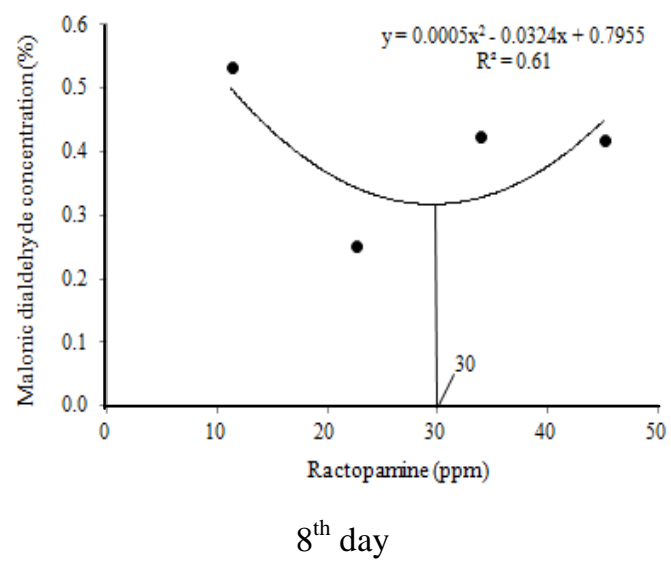

compared to the control, except when a dose of 33.75 ppm was used. At this dose, the concentration of malonic dialdehyde was similar to the control. A quadratic effect $(\mathrm{P}<0.05)$ of ractopamine was observed after 60 days of storage. The optimal dose for reducing the malonic dialdehyde concentration was $24 \mathrm{ppm}$ (Figure 4). As for durability in the freezer, ractopamine had no influence $(\mathrm{P}>0.05)$. All steaks were suitable for consumption at the end of the period of analysis.

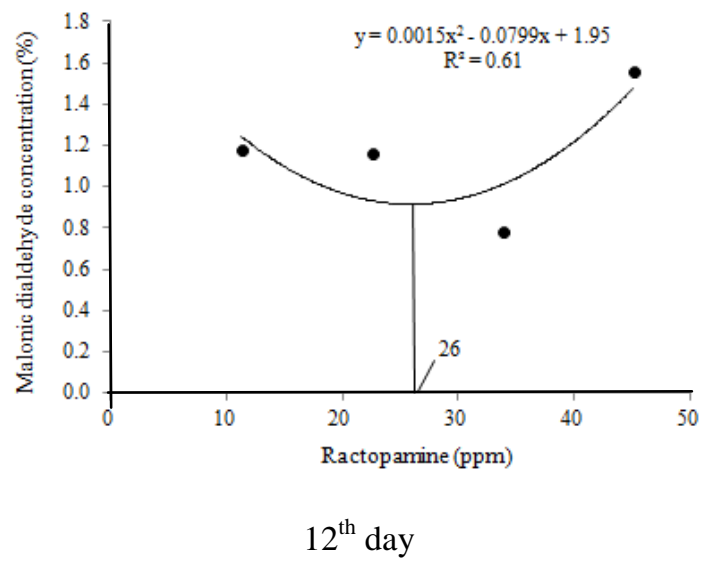

Figure 3. Average malonic dialdehyde concentration $(\mathrm{mg} / \mathrm{kg})$ at $8^{\text {th }}$ and $12^{\text {th }}$ day of storage at $4{ }^{\circ} \mathrm{C}$ of samples of fillets of pacus fed diets containing different levels of ractopamine during finishing phase.

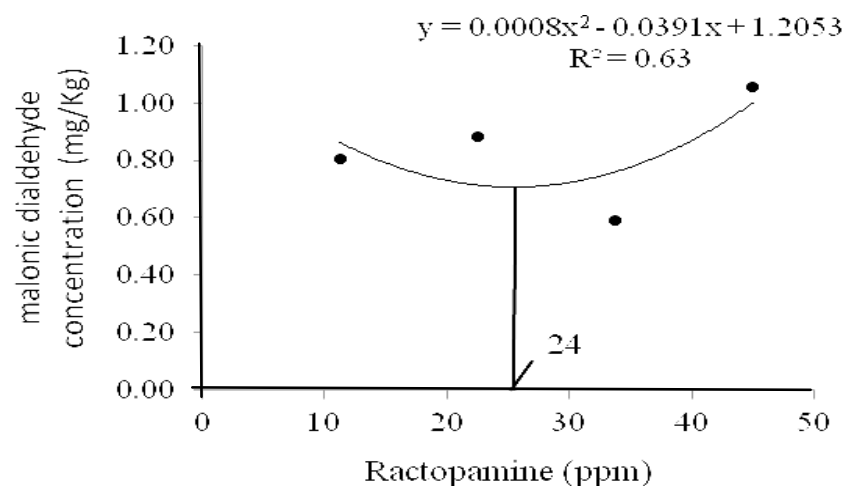

Figure 4. Average concentration of malonic dialdehyde $(\mathrm{mg} / \mathrm{kg})$ at $60^{\text {th }}$ day of storage at $-10^{\circ} \mathrm{C}$ of samples of fillets of pacus fed diets containing different levels of ractopamine during finishing phase.

The thiobarbituric acid reactive substances (TBARS) level represents the rate of lipid oxidation that it is measured by the amount of malonic dialdehyde formed from hydroperoxides. Hydroperoxides are products of the initial reaction between polyunsaturated fatty acids with oxygen (Fernandez et al., 1997; Alvarez et al., 2012). The lipid oxidation processes which occur during the storage of foods cause important changes in their sensory properties, such as rancidity. Rancidity is related to the development of unpleasant flavours and odours associated with food spoilage. In this sense, the use of agents with the aim of reducing or delaying this process is common in food technology to minimise the effects of oxidation, 
thus maintaining the nutritional quality and extending the shelf life of foods (Alvarez et al., 2012).

Generally, the shelf life of cooled fish fillets is relatively short, compared with other meat products. The shelf life has been estimated at 13 to 16 days (Cakli et al. 2007; Kilinc et al., 2007; Alvarez et al., 2008; 2012). This is due to the high content of polyunsaturated fatty acids which makes this product very susceptible to lipid oxidation during storage, a major cause of deterioration (Fraser and Sumar, 1998; Alvarez et al., 2012). In cooled fish meat, the appearance of off-flavours and changes in the colour and texture reduce the sensory quality of the product in a few days, thus shortening the shelf life (Huss, 1995; Alvarez et al., 2012). In this sense, any method used to prolong the shelf life of fish meat would be of great interest to the industry. Considering that one of the effects of ractopamine is a reduction in lipid levels (HajiAbadi et al., 2010) in meat, it is understood that this substance could also influence the effects of lipid oxidation.

Malonic dialdehyde values of $1-2 \mathrm{mg} / \mathrm{kg}$ are considered to be the upper limit above which fish meat is unfit for consumption due to changes in colour and unpleasant flavours (Connell, 1995; Tironi et al., 2010). In the present work, TBARS values were lower than those reported by other authors (Cakli et al., 2007; Kilinc et al., 2007; Kostaki et al., 2009; Alvarez et al., 2012).

In this study, the results indicate that lipid oxidation occurred during storage, as expected, both in the freezer and in the refrigerator. The difference was in the time that elapsed until the product was considered spoiled. The results indicate that a ractopamine dose of 20 or $30 \mathrm{ppm}$ is beneficial in terms of reducing the effect of oxidation. For storage in the refrigerator or freezer, a level of $33.75 \mathrm{ppm}$ was effective.

\section{CONCLUSION}

Ractopamine at $11.25 \mathrm{ppm}$ was effective in reducing the fat content in fillets of pacu, although it increased the formation of peroxides in samples kept in the freezer for 60 days. At a dose of $33.75 \mathrm{ppm}$, ractopamine was effective in reducing the effect of oxidation during storage in the refrigerator or freezer.

\section{ACKNOWLEDGMENT}

$\mathrm{CNPq}$ and FAPEMIG for financial support. UFLA, especially the Veterinary Medicine and Food Science Department that enabled this work.

\section{REFERENCES}

ALVAREZ, A.; GARCIA-GARCIA, B.; GARRIDO, M.D. et al. The influence of starvation time prior to slaughter on the quality of comercial-sized gilthead seabream (Sparus aurata) during ice storage. Aquaculture, v.284, p.106-114, 2008.

ALVAREZ, A.; GARCIA-GARCIA, B.; JORDAN, M.J. et al. The effect of diets supplemented with thyme essential oils and rosemary extract on the deterioration of farmed gilthead seabream (Sparus aurata) during storage on ice. Food Chem., v.132, p.1395-1405, 2012.

ASSOCIATION of official analytical chemistry AOAC. Official methods of analysis. 16.ed. Arlington: AOAC International, 1995. 1025p.

BATISTA, G.M.; LESSI, E.; KODAIRA, M. et al. Alterações bioquímicas post-mortem de matrinxã Brycon cephalus (Günther, 1869) procedente da piscicultura, mantido em gelo. Ciênc Tecnol. Alim., v.24, p.573-581, 2004.

BICUDO, A.J.A.; SADO, R.Y.; CYRINO, J.E.P. Growth performance and body composition of Pacu (Piaractus mesopotamicus) (Holmberg 1887 ) in response to dietary protein and energy levels. Aquac. Nutr., v.16, p.213-222, 2010.

BOSCOLO, W.R.; SIGNOR, A.; FREITAS, J.M.A. et al. Nutrição de peixes nativos. Rev. Bras. Zootec., v.40, p.145-154, 2011.

CAKLI, S.; KILINC, B.; CADUN, A. et al. Quality differences of whole ungutted sea bream (Sparus aurata) and sea bass (Dicentrarchus labrax) while stored in ice. Food Contr., v.18, p.391-397, 2007.

CONNELL, J.J. Control of fish quality. 4. ed. London: Wiley-Blackwell, 1995. 256p.

FERNANDEZ, J.; PEREZ-ALVAREZ, J.A.; FERNANDEZ-LOPEZ, J.A. Thiobarbituric acid test for monitoring lipid oxidation in meat. Food Chem., v.59, p.345-353, 1997. 
FERREIRA, M.S.S.; SOUSA, R.V.; SILVA, V.O. et al. Cloridrato de ractopamina em dietas para suínos em terminação. Act. Scient. Anim. Sci., v.33, p.25-32, 2011.

FRASER, O.; SUMAR, S. Compositional changes and spoilage in fish - an introduction. Nutr. Food Sci., v.5, p.275-279, 1998.

FURUYA, W.M.; PEZZATO, L.E.; BARROS, M.M. et al. Use of ideal protein concept for precision formulation of amino acids level in diets with and without dicalcium phosphate for juvenile Nile tilapia. Aquac. Res., v.35, p.110116, 2004.

HAJI-ABADI, J.S.M.A.; SOOFIANI, M.N.; SADEGHI, A.A. et al. Effects of supplemental dietary 1-carnitine and ractopamine on the performance of juvenile rainbow trout, Oncorhynchus mykiss. Aquac. Res., v.41, p.15821591, 2010.

HUSS, H.H. Quality and quality changes in fresh fish. In: FAO Fisheries Technical Paper 348. Rome: FAO, 1995. Available at: <http://www.fao.org/DOCREP/V7180E/V7180E 00.HTM> Access on: may 5, 2012.

KILINC, B.; CAKLI, S.; CADUN, A. et al. Comparison effects of slurry ice and flake ice pretreatments on the quality of aquacultured sea bream (Sparus aurata) and sea bass (Dicentrarchus labrax) stored at $4^{\circ} \mathrm{C}$. Food Chem., v.104, p.1611-1617, 2007.

KOSTAKI, M.; GIATRAKOU, V.; SAVVAIDIS, N.I. et al. Combined effect of MAP and thyme essential oil on the microbiological, chemical and sensory attributes of organically aquacultured sea bass (Dicentrarchus labrax) fillets. Food Microb., v.26, p.475-482, 2009.

MERSMANN, H.J. Overview of the effects of beta-adrenergic receptor agonists on animal growth including mechanisms of action. J. An. Sci., v.76, p.160-172, 1998.

MERSMANN, H.J. Beta-adrenergic receptor modulation of adipocyte metabolism and growth. J. Anim. Sci., v.80, p.E24-E29, 2002.

MITCHELL, A.D.; SOLOMON, M.B.; STEELE, N.C. Response of low and high protein select lines of pigs to the feeding of the beta-adrenergic agonist ractopamine (phenethanolamine). $J$. Anim. Sci., v.68, p.3226-3232, 1990.
MOCCIA, R.D.; GURURE, R.M.; ATKINSON, J.L. et al. Effects of the repartitioning agent ractopamine on the growth and body composition of rainbow trout Oncorhynchus mykiss, fed tree level of dietary protein. Aquac. Res., v.29, p.687-694, 1998.

MOREIRA, J. Causas da ocorrência de carne PSE em frangos de corte e como controlá-las. In: SEMINÁRIO INTERNACIONAL DE AVES E SUINOS - AVESUI, 4., 2005. Florianópolis SC. Anais... Florianópolis: Gessulli Agribusiness, 2005. p.71-118.

MUSTIN, W.T.; LOVELL, R.T. Feeding the repartitioning agent ractopamine to channel catfish (Ictalurus punctatus) increases weight gain and reduces fat deposition. Aquaculture, v.109, p.145-152, 1993.

POVH, J.A.; RIBEIRO, R.P.; LOPERABARRERO, N.M. et al. Monitoramento da variabilidade genética de pacu, Piaractus mesopotamicus, do programa de aumento de estoque do rio Paranapanema. Arq. Bras. Med. Vet. Zootec., v.61, p.1191-1195, 2009.

ROSENVOLD, K.; ANDERSEN, H.J. Factors of significance for pork quality - a review. Meat Sci., v.64 p.219-237, 2003.

SALEM, M.; LEVESQUE, H.; MOON, T.W. et al. Anabolic effects of feeding $\beta 2$-adrenergic agonists on rainbow trout muscle proteases and proteins. Comp. Biochem. Physiol. Part A: Mol. Int. Physiol., v.144, p.145-154, 2006.

TANAMATI, A.; STEVANATO, F.B.; VISENTAINER, J.E.L. et al. Fatty acid composition in wild and cultivated pacu and pintado fish. Eur. J. Lip. Sci. Techn., v.111, p.183-187, 2009.

TARLADGIS, B.G.; WATTS, B.M.; YOUNATHAN, M.T. A destillation method for the quantitative determination of malonaldehyde in rancid foods. J. Am. Oil Chem. Soc., v.37, p.44-48, 1960.

TIRONI, V.A.; TOMAS, M.C.; ANON, M.C. Quality loss during the frozen storage of sea salmon (Pseudopercis semifasciata). Effect of rosemary (Rosmarinus officinalis L.) extract. Food Sci. Techn., v.43, p.263-272, 2010. 
VAN den BERG, G.W.; MOCCIA, R.D. Growth performance and carcass composition of rainbow trout, Oncorhynchus mykiss (Walbaum), fed the $\beta$-agonist ractopamine. Aquac. Res., v.29, p.469479, 1998.

VAN den BERG, G.W.; LEATHERLAND, J.F.; MOCCIA, R.D. The effects of the beta-agonist ractopamine in growth hormone and in intermediate metabolite concentrations in rainbow trout, Oncorhynchus mykiss. Aquac. Res., v.29, p79-87, 1998.

VAN HEESWIJK, J.C.F.; VIANEN, G.J.; VAN DEN THILLART, G.E.E.J.M. The adrenergic control of hepatic glucose and FFA metabolism in rainbow trout (Oncorhynchus mykiss): increased sensitivity to adrenergic stimulation with fasting. Gen. Comp. End., v.145, p.51-61, 2006.
WEBSTER, C.D.; TUI, L.G.; TIDWELL, J.H. et al. Effects of feeding the repartitioning agent L644,969 on growth and body composition of blue catfish, Ictalurus furcatus, fed diets containing two protein levels reared in cages. Aquaculture, v.134, p.247-256, 1995. 